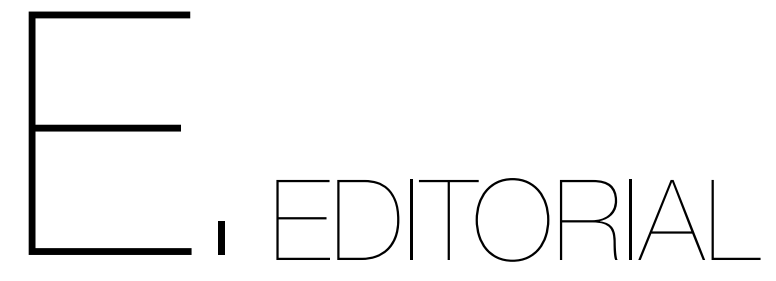

\section{O MICROMUNDO}

Num momento em que ainda vivemos a grave situação pandémica que afeta todo o globo e em que se assistiu a um grande progresso científico, nomeadamente no desenvolvimento em tempo recorde de várias e inovadoras vacinas, importa refletir sobre as consequências deste período verdadeiramente atíicico.

Seguindo uma tendência que já se vinha a demonstrar, a doença mental parece ter aumentado ainda mais com o início da pandemia, sobretudo na sua fase inicial, sendo ainda discutido se esse aumento persistiu com o desenrolar da situação.

Em todo o caso, o alargado conjunto de doenças psiquiátricas constitui um peso enorme no conjunto total das doenças, destacando-se a depressão, a ansiedade e as perturbações do tipo psicótico como a bipolaridade ou a esquizofrenia, a que se acrescentam as várias toxicodependências. A incapacidade gerada por estas doenças assim como o seu impacto nas famílias, cuidadores e sistemas de saúde tem levado a apurada investigação científica, seja ao nível do desenvolvimento de novos medicamentos seja na procura de soluções complementares a esta. Dentro destas últimas, a nutrição e a alimentação assumem especial importância no contexto desta revista.

Neste número da Acta Portuguesa de Nutrição, um artigo de Charneca e Guerreiro revê a evidência acerca do papel da microbiota intestinal na génese e eventual tratamento de algumas doenças psiquiátricas. As conclusões apontam para a existência de uma relação entre determinadas populações microbianas e a prevalência ou gravidade de algumas doenças psiquiátricas. No entanto, aquilo a que podemos chamar o "fechar do círculo", ou seja, a utilização desse conhecimento para efetivamente aumentarmos as ferramentas ao dispor para o tratamento dos doentes revela-se ainda bastante distante. É, aliás, um ponto comum à investigação do papel da microbiota na doença e que, se por um lado nos deve levar a usar da necessária prudência na extrapolação de resultados da investigação básica para a clínica, não deixa de constituir um forte estímulo para a continuação da investigação científica na área. Acresce que estão atualmente disponíveis técnicas muito avançadas para a determinação da muito complexa população bacteriana intestinal, que certamente proporcionarão novos avanços no esclarecimento cabal do papel deste micromundo que nos habita e que connosco interage.

Prosseguindo o seu trabalho de divulgar os trabalhos de qualidade, a Acta Portuguesa de Nutrição será também um meio privilegiado de publicação deste tipo de trabalhos para o crescente número de investigadores que a eles se dedicam.

\section{Nuno Borges}

Diretor da Acta Portuguesa de Nutrição 